\title{
Introducing the Asian Pacific Island Nursing Journal (APINJ)
}

Asian / Pacific Island Nursing Journal

October-December 2014: 1-2

(C) The Author(s) 2014

DOI: $10.1177 / 2373665814557801$

apn.sagepub.com

(SAGE

\section{Carolyn Yucha, RN, PhD, FAAN ${ }^{1}$}

As the Dean of the Schools of Nursing and Allied Health Sciences at the University of Nevada Las Vegas (since 2004) and the Editor of Biological Research for Nursing (since 2002), I was both honored and delighted when Dr. Inouye shared with me that the Asian American/Pacific Islander Nurses Association (AAPINA) was interested in developing a journal and asked me to serve as consulting editor. I immediately arranged a phone call with Daniel Ruth, Senior Acquisitions Editor with Sage Publications, a leading international publisher of journals, books, and electronic media for academic, educational, and professional markets since 1965.

After many discussions and a few revisions of the journal proposal, Sage agreed to publish the Asian Pacific Island Nursing Journal (APINJ) as an online open-access journal. This is wonderful because it means that the work of AAPINA members and those of others doing work on the Asian American/Pacific Islander population will have a venue for rapid dissemination of their work. The content is available to readers anywhere and anytime at no cost and may easily incorporate multiple media sources such as links, images and sound. This will improve the research in this area and ultimately improve the healthcare of this population. The business advantage of this model is that this can be done cost-effectively without a guarantee of subscriptions.
Online open-access journals have been the subject of debate around recent publishing models. Many professionals have resisted this model and categorized all open-access journals as second rate. Some of these have been referred to as "Predatory" journals by Jeffrey Beall, an academic librarian, because of the high author charges and poor or nonexistent review. This has led to confusion for authors and editors in the nursing profession. Therefore, it is appropriate to distinguish between these predatory journals and APINJ, published by a reputable publisher. The table below provides guidelines for evaluating the integrity of a journal. It has been adapted from "Predatory Publishing: What Editors Need to Know" written by the INANE Predatory Publishing Collaborative and published in the September 2014 issue of Nurse Author \& Editor. Please keep these issues in mind when submitting manuscripts to any journals, especially those that you have not heard of or seen. Also, you can rest assured that APINJ will develop and evolve into a substantial journal with integrity. Your submissions to APINJ will assure the success and continuance of this journal.

Please keep these issues in mind when submitting manuscripts to any journals, especially those that you have not heard of or seen. Also, you can rest assured that APINJ will develop and evolve into a substantial journal with integrity. Your submissions to APINJ will assure the success and continuance of this journal.

\footnotetext{
${ }^{1}$ University of Nevada, Las Vegas, Las Vegas, NV, USA Corresponding Author: University of Nevada, Las Vegas, Las Vegas, NV, USA Email: carolyn.yucha@unlv.edu
} 
Guidelines for Evaluating the Integrity of a Journal.

\begin{tabular}{|c|c|c|c|}
\hline Question & What to Look for & Red Flags & APPINA \\
\hline $\begin{array}{l}\text { Who is the Editor in } \\
\text { charge of journal } \\
\text { content? }\end{array}$ & $\begin{array}{l}\text { A person who has a } \\
\text { reputation in the discipline. } \\
\text { Direct contact information } \\
\text { for the editor is provided. }\end{array}$ & $\begin{array}{l}\text { You cannot find any } \\
\text { evidence of the } \\
\text { Editor's standing in } \\
\text { the discipline. } \\
\text { There is no } \\
\text { contact } \\
\text { information. }\end{array}$ & $\begin{array}{l}\text { Dr. Jillian Inouye is } \\
\text { well- known for her } \\
\text { research in this } \\
\text { population. } \\
\text { - Her contact } \\
\text { information is } \\
\text { provided. }\end{array}$ \\
\hline $\begin{array}{l}\text { What is the journal's } \\
\text { process for assuring } \\
\text { quality of content? }\end{array}$ & $\begin{array}{l}\text { A clear description of } \\
\text { the process for review } \\
\text { of manuscripts prior to } \\
\text { publication is stated. } \\
\text { The names \& duties of the } \\
\text { editorial, advisory or } \\
\text { review panel members are } \\
\text { listed. }\end{array}$ & $\begin{array}{l}\text { A promise of rapid } \\
\text { review \& publication } \\
\text { (quality reviews take } \\
\text { time). } \\
\text { - Mystification of those } \\
\text { who are involved in the } \\
\text { review process. }\end{array}$ & $\begin{array}{l}\text { The review process is } \\
\text { stated \& is expected to } \\
\text { take } 4 \text { weeks. } \\
\text { The editorial board } \\
\text { is clearly shown on } \\
\text { the webpage. }\end{array}$ \\
\hline $\begin{array}{l}\text { Does the journal have } \\
\text { sound business \& } \\
\text { publishing practices? }\end{array}$ & $\begin{array}{l}\text { - The journal \& its publisher } \\
\text { is a member of COPE. } \\
\text { - The journal is in the } \\
\text { INANE/NA\&E Directory of } \\
\text { Nursing Journals. } \\
\text { - If the journal shows an } \\
\text { impact factor, it is verifiable } \\
\text { in the Journal citation } \\
\text { Reports (Web of Science) }\end{array}$ & $\begin{array}{l}\text { The publisher/journal } \\
\text { is on Beall's List at } \\
\text { Scholarly Q\&A. } \\
\text { - The journal name or } \\
\text { other information is } \\
\text { suspiciously like another } \\
\text { journal. } \\
\text { - The journal/publisher } \\
\text { solicits manuscript } \\
\text { using excessively } \\
\text { complimentary emails. }\end{array}$ & $\begin{array}{l}\text { - Sage Publications is a } \\
\text { member of COPE. } \\
\text { The journal has } \\
\text { been vetted for } \\
\text { inclusion \& listed in } \\
\text { the INANE NA\&E } \\
\text { Directory of } \\
\text { Nursing Journals. } \\
\text { - It takes 3-5 years } \\
\text { before a new journal } \\
\text { will be eligible for } \\
\text { consideration by the } \\
\text { Web of Science. }\end{array}$ \\
\hline $\begin{array}{l}\text { Are there author } \\
\text { processing charges? }\end{array}$ & $\begin{array}{l}\text { Information about author } \\
\text { processing charges (APC), } \\
\text { if any, is clear \& easily } \\
\text { accessible. }\end{array}$ & $\begin{array}{l}\text { Processing charges are } \\
\text { not readily accessible or } \\
\text { are unclear. }\end{array}$ & $\begin{array}{l}\text { Processing charges are } \\
\$ 500 \text { per article for } \\
\text { APPINA member \& } \\
\$ 1000 \text { for non- } \\
\text { APPINA members. }\end{array}$ \\
\hline $\begin{array}{l}\text { Is the journal associated } \\
\text { with a professional } \\
\text { organization? }\end{array}$ & $\begin{array}{l}\text { - Association with a known } \\
\text { professional organization is } \\
\text { clearly stated. }\end{array}$ & $\begin{array}{l}\text { The association, if } \\
\text { any, is completely } \\
\text { unknown to you. }\end{array}$ & $\begin{array}{l}\text { - The journal is } \\
\text { associated with } \\
\text { APPINA. }\end{array}$ \\
\hline $\begin{array}{l}\text { Is the publisher a } \\
\text { longstanding publisher } \\
\text { of scientific literature? }\end{array}$ & $\begin{array}{l}\text { The name of the publisher } \\
\text { is well known. The } \\
\text { publisher publishes other } \\
\text { journals that you respect. }\end{array}$ & $\begin{array}{l}\text { You have never heard } \\
\text { of the publisher \& are } \\
\text { not familiar with the } \\
\text { journals they publish. }\end{array}$ & $\begin{array}{l}\text { - Sage has been in the } \\
\text { publishing business } \\
\text { for } 50 \text { years. }\end{array}$ \\
\hline
\end{tabular}

\section{Declaration of Conflicting Interests}

The author declared no potential conflicts of interest with respect to the research, authorship, and/or publication of this article.

\section{Funding}

The author received no financial support for the research, author- ship, and/or publication of this article.

\section{Sources and Useful Websites}

Jeffrey Beall's List of Potential, Possible or

Probable Predatory Scholarly Open-Access

Publishers, http://scholarl yoa.com/publishers/

COPE Committee on Publication Ethics, http://publica tionethics.org/
INANE/Nurse Author \& Editor Directory of Nursing Journals, http://nursingeditors.com/journalsdirectory/

International Academy of Nursing Editors, http://nursing editors.com/ Nurse Author \& Editor, http://www.nurseauthoreditor.com/ 